mgr Anna Krawczuk

Centrum Edukacji Nauczycieli w Białymstoku

anak@cen.bialystok.pl

\title{
FUNDRAISING BIBLIOTECZNY NA PRZYKŁADZIE BIBLIOTEKI PEDAGOGICZNEJ CENTRUM EDUKACJI NAUCZYCIELI W BIAŁYMSTOKU
}

\author{
Library fundraising on the example of the Pedagogical \\ Library of Education Center of Teachers in Bialystok
}

\begin{abstract}
Abstrakt
Środki budżetowe przekazywane przez Samorząd Województwa na funkcjonowanie Biblioteki Pedagogicznej CEN w Białymstoku nie dają możliwości realizacji zadań statutowych w sposób satysfakcjonujący. W podobnej sytuacji są inne biblioteki. Zamiarem autorki jest podzielenie się doświadczeniem i pokazanie metod fundraisingowych, które stosuje Biblioteka Pedagogiczna, aby zapewnić sobie stabilizację finansową i fundusze na dalszy rozwój.
\end{abstract}

Słowa kluczowe: finansowanie bibliotek, biblioteka pedagogiczna, metody fundrasingu, Biblioteka Pedagogiczna Centrum Edukacji Nauczycieli w Białymstoku.

\begin{abstract}
The budgetary funds of Pedagogic Library CEN in Białystok provided by the voivodeship's self-government are insufficient to carry out the statutory tasks at a satisfactory level. This problem concerns other libraries as well. The purpose of this article is to share the author's experience and to show the fundraising methods used by the Pedagogic Library in order to secure its financial stability and funds for further development.
\end{abstract}

Keywords: library funding, pedagogic library, fundraising methods, the Pedagogical Library Education Center of Teachers in Bialystok. 
Biblioteki pedagogiczne są częścią polskiego systemu oświaty i tak jak większość szkół i placówek oświatowych borykają się z wieloma problemami natury finansowej. Prowadzenie bibliotek pedagogicznych należy do zadań samorządu województwa. Środki budżetowe na oświatę i edukację trafiają do samorządów w postaci części oświatowej subwencji ogólnej. Jednakże są one niewystarczające i samorządy dopłacają do zadań oświatowych z własnych dochodów. Powody finansowe stały się m.in. przyczyną likwidacji wszystkich filii bibliotecznych $\mathrm{w}$ miastach powiatowych województwa podlaskiego. Niski poziom dotacji budżetowej na realizację zadań statutowych Biblioteki Pedagogicznej Centrum Edukacji Nauczycieli (Biblioteka Pedagogiczna CEN) w Białymstoku nie umożliwia pełnej i efektywnej realizacji zadań, dlatego koniecznym staje się podejmowanie inicjatyw związanych z pozyskaniem środków z innych źródeł. W przypadku Biblioteki Pedagogicznej CEN tymi źródłami są projekty: Unii Europejskiej, projekty ze środków finansowych Urzędu Miejskiego w Białymstoku i Urzędu Marszałkowskiego Województwa Podlaskiego oraz pozyskane w ramach współpracy z innymi instytucjami.

Rozporzadzenie Ministra Edukacji Narodowej (MEN) $z$ dnia 28 lutego 2013 r. w sprawie szczegółowych zasad działania publicznych bibliotek pedagogicznych określiło nowe zadania dla bibliotek pedagogicznych - „organizowanie i prowadzenie wspomagania:

a) szkół i placówek w realizacji zadań dydaktycznych, opiekuńczych i wychowawczych, w tym wykorzystania technologii informacyjno-komunikacyjnej;

b) bibliotek szkolnych, w tym w zakresie organizacji i zarządzania biblioteką szkolną"1.

Według powyższego Rozporządzenia „Wspomaganie polega na:

1. Zaplanowaniu i przeprowadzeniu $\mathrm{w}$ związku z potrzebami szkoły lub placówki działań, mających na celu poprawę jakości pracy szkoły lub placówki, obejmujących:

a) pomoc w diagnozowaniu potrzeb szkoły lub placówki;

b) ustalenie sposobów działania prowadzących do zaspokojenia potrzeb szkoły lub placówki;

c) zaplanowanie form wspomagania i ich realizację;

1 Rozporzadzenie Ministra Edukacji Narodowej z dnia 28 lutego 2013 r. w sprawie szczegółowych zasad działania publicznych bibliotek pedagogicznych. Dz.U. 2013, poz. 369. 
d) wspólną ocenę efektów realizacji zaplanowanych form wspomagania i opracowanie wniosków $\mathrm{z}$ ich realizacji.

2. Organizowaniu i prowadzeniu sieci współpracy i samokształcenia dla nauczycieli, którzy w zorganizowany sposób współpracują ze sobą w celu doskonalenia swojej pracy, w szczególności przez wymianę doświadczeń" ${ }^{\prime \prime}$.

To nowe zadanie wymaga nowych kompetencji i umiejętności bibliotekarzy. Należało zaplanować szkolenia bibliotekarzy, przygotowujące ich do pełnienia nowych zadań. Szkolenia wiążą się z nakładami finansowymi, które dodatkowo obciążyłyby budżet placówki.

W latach 2010-2015 Ośrodek Rozwoju Edukacji (ORE) w Warszawie realizował projekt System doskonalenia nauczycieli oparty na ogólnodostępnym kompleksowym wspomaganiu szkół. Celem była poprawa jakości systemu doskonalenia nauczycieli. Jednym z działań było przygotowanie zaplecza kadrowego i merytorycznego, służącemu doskonaleniu nauczycieli i wspomaganiu pracy szkół. Biblioteka Pedagogiczna CEN, jako placówka systemu edukacji, która zgodnie z zapisem Rozporządzenia MEN „służy w szczególności wspieraniu procesu kształcenia i doskonalenia nauczycieli, a także wspieraniu działalności szkół, w tym bibliotek szkolnych" była beneficjentem tego projektu. Nauczyciele bibliotekarze CEN w ramach projektu uczestniczyli w szkoleniach, konferencjach oraz zawiązali sieć współpracy i samokształcenia, aby poznać specyfikę nowej formy doskonalenia, jaką jest wspomaganie. Przyniosło to wymierne efekty, które przełożyły się na wsparcie powiatów, które realizowały w latach 2013-2015 pilotażowe kompleksowe wspomaganie rozwoju szkół, a także na ofertę doskonalenia adresowaną do bibliotekarzy szkolnych.

W wyniku podjętych działań od 2014 r. na platformie e-learningowej CEN funkcjonuje sieć współpracy i samokształcenia nauczycieli bibliotekarzy szkolnych Białegostoku i powiatu białostockiego, która zrzesza 299 osób. Sieć jest formą wspomagania, która umożliwia samokształcenie i kooperację, ułatwia wymianę doświadczeń, tworzenie nowych rozwiązań oraz poszerzenie kompetencji. Zadania, nakreślone do realizacji przez społeczność sieci, odbywają się podczas spotkań warsztatowych w bibliotece CEN oraz na platformie e-learningowej moodle.

Kolejnym projektem, w który włączyła się Biblioteka Pedagogiczna CEN jest projekt Samorządu Województwa Podlaskiego Wdrażanie elektronicznych ustug dla ludności województwa podlaskiego, część II Administracja

2 Tamże. 
samorzadowa. Od 2016 r. biblioteka CEN współtworzy zasoby Centralnego Repozytorium Treści Dydaktycznych w Podlaskiej Platformie Edukacyjnej, która powstała jako efekt wspomnianego projektu.

\section{Rysunek 1. Platforma - Sieć współpracy nauczycieli bibliotekarzy SNB}

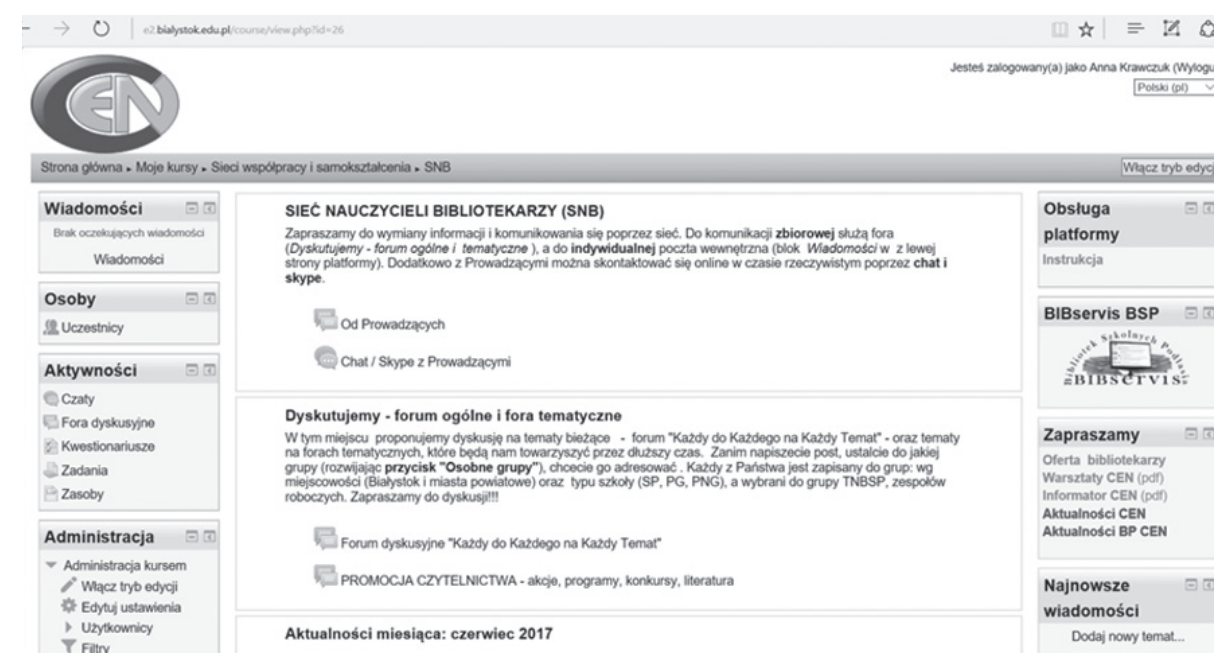

Źródło: Centrum Edukacji Nauczycieli w Białymstoku. Tryb dostępu: http://e2.bialystok.edu.pl/course/view.php?id=26 [18 lutego 2017].

\section{Rysunek 2. Podlaska Platforma Edukacyjna - biblioteki szkolne}

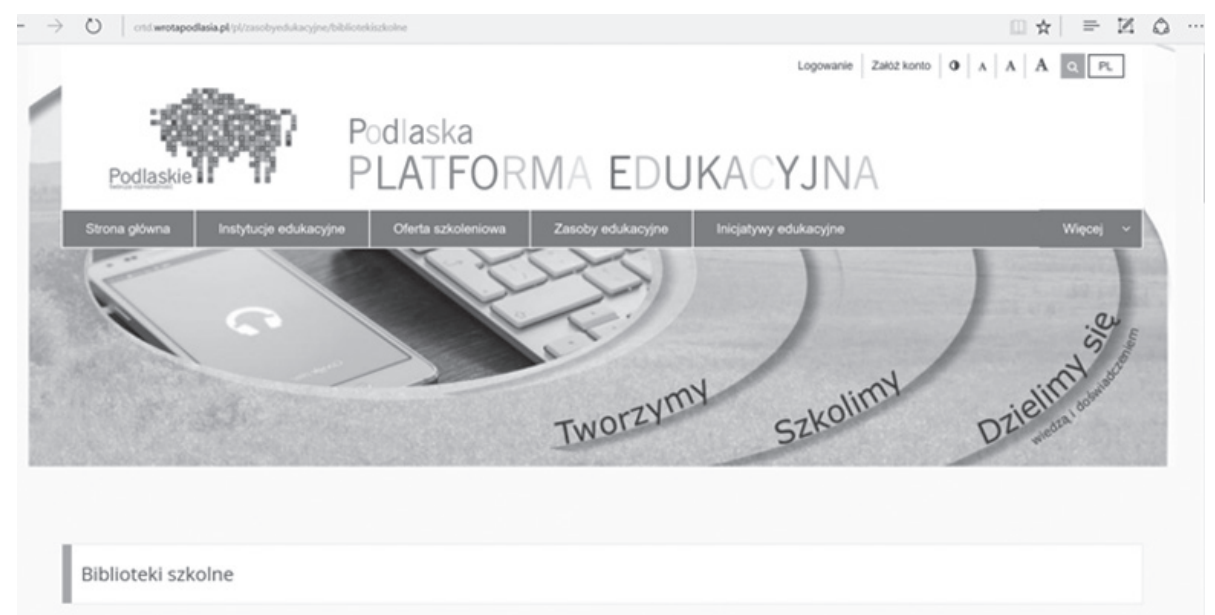

Źródło: Podlaska Platforma Edukacyjna. Tryb dostępu: http://crtd.wrotapodlasia. $\mathrm{pl} / \mathrm{pl} /$ zasobyedukacyjne/bibliotekiszkolne/ [18 lutego 2017]. 


\section{Rysunek 3. Podlaska Platforma Edukacyjna - biblioteki szkolne}

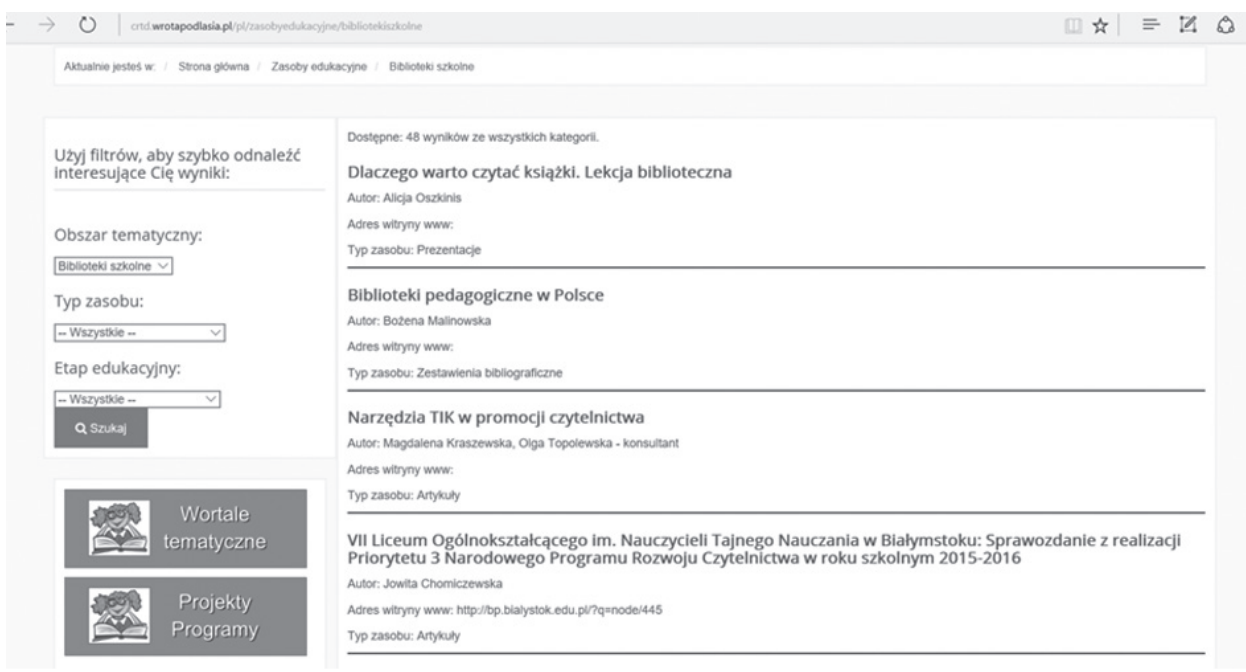

Źródło: Podlaska Platforma Edukacyjna. Tryb dostępu: http://crtd.wrotapodlasia.pl/ pl/zasobyedukacyjne/bibliotekiszkolne/ [18 lutego 2017].

Bibliotekarze szkolni uzyskali możliwość dostępu do takiego miejsca w sieci, gdzie zgromadzone zostały materiały informacyjne, zasoby dydaktyczne, scenariusze lekcji bibliotecznych.

Bibliotekarze z CEN w Białymstoku opracowują i realizują także projekty edukacyjne mające na celu rozwijanie czytelnictwa wśród dzieci i młodzieży oraz prezentację nauczycielom nowoczesnych form i metod pracy z książką. Od kilku lat we współpracy z Towarzystwem Nauczycieli Bibliotekarzy Polskich Oddział w Białymstoku realizowane są kolejne edycje projektu Podlaskie spotkania $z$ pisarzami. Środki finansowe na realizację pozyskuje Towarzystwo przystępując do konkursów organizowanych przez Urząd Marszałkowski oraz Urząd Miejski w Białymstoku. W ramach projektu uczniowie białostockich szkół odbywają spotkania autorskie z wybitnymi autorami współczesnej literatury dziecięcej i młodzieżowej. Przygotowywane są także konkursy ze znajomości twórczości zaproszonych gości.

Wymierne efekty uzyskuje biblioteka w wyniku współpracy z Instytutem Goethego w Warszawie, dzięki której powstała Medioteka Języka Niemieckiego, doposażana systematycznie w publikacje i zbiory audiowizualne. W 2014 r. Instytut przekazał środki finansowe na remont i wyposażanie medioteki. 
W 2016 r. nauczyciele bibliotekarze wystąpili z projektem Niemiecka literatura - czytamy to, co dobre, który został pozytywnie zaopiniowany i uzyskał dotację finansową Instytutu na realizację. W projekcie przeprowadzono 106 lekcji dla 2228 uczniów.

Projektów, które realizuje Biblioteka Pedagogiczna CEN, nie rozpoczynamy od pozyskiwania potencjalnych sponsorów, ale od pomysłów, które potem przyjmują kształt konkretnego przedsięwzięcia. Tak rozumiemy fundraising - jako proces poszukiwania wsparcia dla własnych pomysłów. Nie zaczyna się on, ani nie kończy na napisaniu wniosku, czy sformułowaniu prośby o dofinansowanie. To sekwencja działań: od pomysłu poprzez poszukiwanie osób i instytucji współpracujących, do realizacji. Instytucje, które podejmują $\mathrm{z}$ nami współpracę, wspierają nasze projekty, a w konsekwencji przyczyniają się do rozwiązania istotnych problemów, jak również wspomagają nauczycieli w realizacji ich zadań. Korzyści ze współpracy są obopólne, biblioteka otrzymuje dotację finansową na realizację projektów, instytucja, która przekazała środki - promocję, komunikację ze środowiskiem edukacyjnym. Jest to również element budowy prestiżu instytucji.

\section{Bibliografia}

1. Krawczuk A.: Biblioteki pedagogiczne i ich zasoby w kontekście nowych zadań. Tryb dostępu: https:/www.doskonaleniewsieci.pl/Upload/Files/1/samouczki/poradnik-biblioteki/modul_III/ekran1/Bibl_pedagog\%20i\%20ich\%20zasoby_A.Krawczuk.pdf [18 lutego 2018].

2. Niemiec R.: Alternatywne źródła pozyskiwania środków finansowych przez ednostki oświatowe. Tryb dostępu: http://www.koobe.pl/fragmenty/3491747/66352/alternatywne-zrodla-pozyskiwania-srodkow-finansowych -przez-jednostki-o-demo.pdf [18 lutego 2018].

3. Rozporzadzenie Ministra Edukacji Narodowej z dnia 28 lutego 2013 r. w sprawie szczegółowych zasad działania publicznych bibliotek pedagogicznych. Dz.U. 2013, poz. 369.

4. Wyrzykowska E.: Finansowanie Bibliotek Pedagogicznych. „Biuletyn EBIB” 2009, nr 8(108). Tryb dostępu: http://www.ebib.pl/2009/108/a.php?wykrzykowska [18 lutego 2018]. 